\title{
Plasma and erythrocyte magnesium in Huntington's chorea
}

\author{
LAURA W. FLEMING, MONTAGU G. BARKER, AND WILLIAM K. STEWART \\ From the Departments of Medicine and Psychiatry, University of St. Andrews, \\ Queen's College, Dundee, Scotland
}

Although magnesium activates many enzyme systems in vitro, there is as yet no conclusive evidence that any specific defect in enzyme function producing disease can be attributed solely to alterations in magnesium metabolism. Physiologically, magnesium depresses both central and peripheral nervous systems, and is thought to act by inhibiting the release of acetylcholine at the neuromuscular junction and in the sympathetic ganglia (Castillo and Engbaek, 1954).

The normal human body contains a total of approximately $2,000 \mathrm{mEq}$. magnesium, half of which is to be found in bone. The remainder is predominantly intracellular: less than $2 \%$ of total body content circulates in the plasma.

Magnesium deficiency is known to increase motor irritability. Hypomagnesaemia in man has been associated with muscular twitching or tremor, including choreiform movements, agitation, delirium, and convulsions (Flink, McCollister, Prasad, Melby, and Doe, 1957). More specifically it has been reported in a patient with choreoathetosis (Randall, Rossmeisl, and Bleifer, 1959). In the majority of these instances, the clinical picture has been complicated by concurrent deficiencies, more or less severe, of other ions. Furthermore, patients with hypomagnesaemia exhibiting none of these symptoms have been observed (Martin, Mehl, and Wertman, 1952).

Hypermagnesaemia can accompany uraemia, and in these cases probably contributes to the general physiological depression of the cardiovascular and nervous systems (Barker, 1960). It is not at present possible to separate the magnesium effects from those of associated hyperkalaemia and other abnormalities, except in the prolongation of the $\mathbf{P}-\mathbf{R}$ interval, due to magnesium rather than potassium excess.

In view of the reports of choreiform movements associated with magnesium deficiency, various authors have searched for a disturbance of magnesium metabolism in patients with Huntington's chorea. The results of studies by Kenyon and Hardy
(1963) surprisingly suggested that erythrocyte magnesium may be increased in some patients, but subsequent investigators (Jones, Desper, and Flink, 1965; Bruyn, Mink, and Caljé, 1965) have refuted the idea of any significant defect in at least that part of magnesium metabolism which is at present available to systematic study.

The present investigation was undertaken on 10 well-documented cases of Huntington's chorea in an attempt to confirm one of the two conflicting reports outlined above, using atomic absorption spectrophotometry to estimate magnesium concentrations.

\section{METHODS}

Only those patients who showed both choreiform movements and dementia beginning in middle life were included in this series. In addition, all had a family history of Huntington's chorea confirmed through hospital records. There was no clinical evidence of renal disease in any patient.

In all cases except one (J.B.), postprandial venous blood samples were collected and transferred immediately into bottles containing 100 I.U. heparin. The haematocrit was measured, duplicate $2 \mathrm{ml}$. samples of whole blood were mixed with $3 \mathrm{ml}$. deionized water to lyse the erythrocytes, and plasma was separated within two hours of collection. The samples from J.B. were taken in the middle of the afternoon, due to his being in a distant hospital.

Methods of estimation were as follows:- Calcium by the method of Beale and Bostrom (1963), utilizing complexometric titration with Corinth calcium reagent as indicator; phosphorus by that of Fiske and Subbarow (1925); total protein, using a modified biuret reagent, by that of Keyser (1961). Magnesium in both plasma and lysed whole blood was measured by atomic absorption spectrophotometry after precipitation of protein with trichloroacetic acid (Fleming and Stewart, 1966). Erythrocyte magnesium $\left(\mathrm{Mg}_{\mathrm{E}}\right)$ in $\mathrm{mEq}$. per litre was calculated using the formula (Bruyn et al., 1965).

$$
1.216 \times \mathrm{Mg}_{\mathrm{E}}=\frac{100}{\mathrm{H}}\left(\mathrm{Mg}_{\mathrm{WB}}-\frac{100-\mathrm{H}}{100} \cdot \mathrm{Mg}_{\mathrm{P}}\right)
$$

where $\mathrm{H}$ is the haematocrit (per cent), and $\mathbf{M g}_{\mathrm{WB}}$ and 
$\mathrm{Mg}_{\mathrm{P}}$ represent the magnesium content in $\mathrm{mg}$. per $100 \mathrm{ml}$. of whole blood and plasma respectively.

\section{RESULTS}

The normal range of plasma magnesium using our method has been established by estimating the plasma concentration of 82 blood donors, and the result obtained $(1.61 \pm 0.08 \mathrm{mEq}$. per litre) agrees with those of other investigators. There is no age or sex difference (Fleming and Stewart, 1966). Normal erythrocyte magnesium concentration was determined in 20 subjects, 10 blood donors and 10 hospital staff, and the mean value obtained was $4.87 \pm 0.30 \mathrm{mEq}$. per litre. This is slightly lower than the mean obtained by Bruyn et al. (1965) using the same method, but agrees with the results of Seller, Ramirez-Muxo, Brest, and Moyer (1965), and falls within the lower half of the normal range quoted by Jones, Desper, and Flink (1965) and Rizek, Dimich, and Wallach (1965). Our standard deviation $(0 \cdot 30)$ is less than that found by others.

Plasma and erythrocyte magnesium concentrations in the patients with Huntington's chorea were measured several times over the course of nine months (Fig. 1). There was no significant variation in the plasma magnesium with time, and only five of 30 estimations were outside the normal range. Taking the average obtained on four separate occasions, two of the patients had an average plasma magnesium concentration outside the normal range, but in each case the increase was minimal. The mean for the 10 patients $(1.73 \mathrm{mEq}$. per litre) does not indicate a significant deviation from the normal mean (Student's $t=1 \cdot 31$ ). Erythrocyte magnesium concentration was within the normal range in nine of the 10 patients on each occasion measured. The exception (M.A.) was only marginally higher, and the overall mean was well within the normal range. The erythrocyte to plasma magnesium ratio was also normal in the 10 patients. Erythrocyte magnesium concentration was highest in the two patients with the longest duration of illness, and Fig. 2 shows the correlation of erythrocyte magnesium with duration of illness in eight of our 10 patients, where duration could be accurately established. The two patients indicated by open circles were not included in the calculations for the regression line, but were placed on the graph at their probable duration points. In these two cases the duration of illness would possibly be longer, but certainly not shorter, duration being defined as the time since the onset of first symptoms, either mental or choreic.

\section{Erythrocyte $\mathrm{Mg}$}

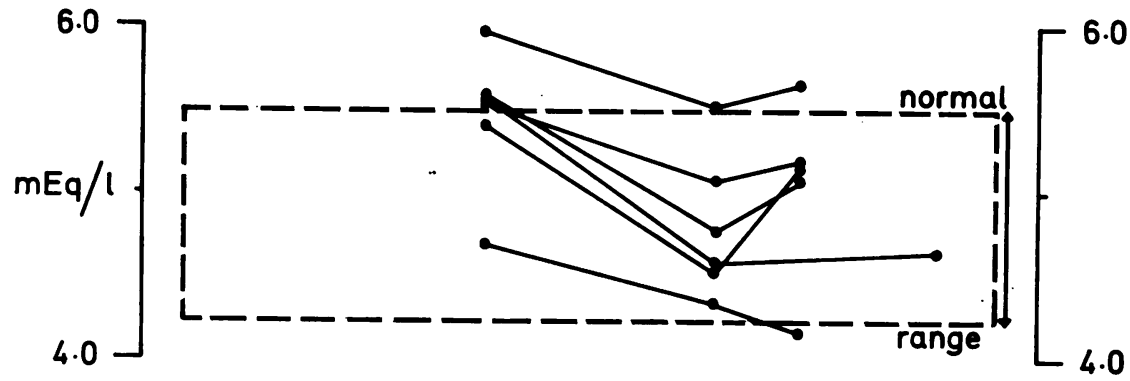

FIG. 1. Plasma magnesium levels in eight patients and erythrocyte magnesium concentration in six patients with Huntington's chorea, compared with the normal range.

\section{Plasma Mg}

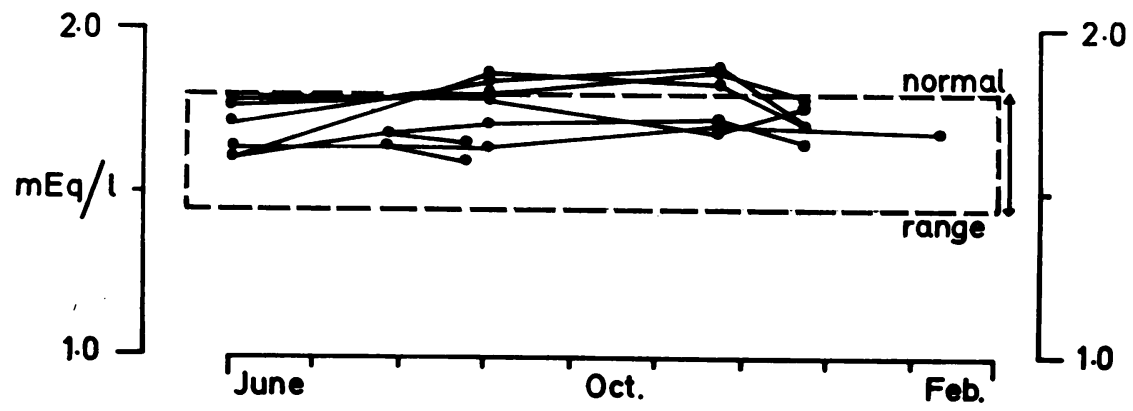




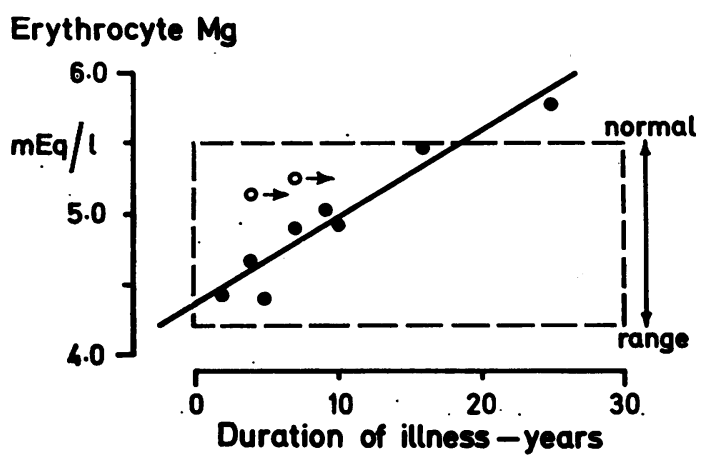

FIG. 2. The correlation of erythrocyte magnesium concentration and duration of illness. The open circles represent two patients whose dates of onset of symptoms were not known accurately.

There was no correlation between plasma magnesium concentration and either age or duration of illness, nor was there any correlation between erythrocyte magnesium and age, except that the two patients with the longest duration of illness and highest erythrocyte magnesium concentration were older than the mean age. The oldest patient in our series (N.C.) actually had the lowest erythrocyte magnesium concentration (Table I).

Serum calcium, phosphorus, and total protein showed no deviation from normal (Table I) with resultant normal calcium-magnesium-phosphorus products (Eliel, Smith, and Thomsen, 1960).

\section{DISCUSSION}

It has been pointed out many times (MacIntyre,
Hanna, Booth, and Read, 1961; Miller, 1963; Welt and Gitelman, 1965) that plasma or serum magnesium levels are a poor indication of tissue deficiency or excess; although patients with hypomagnesaemia may be deficient, tissue deficiency can be present with normal plasma levels. In an effort to avoid measuring only plasma, investigators have studied erythrocytes as being the most accessible human cells, despite their lack of similarity to actual tissue cells. Until biopsy methods are perfected and tissue cells from live human subjects become more readily available they do represent the 'next best thing', and as such warrant investigation. It has been stated that the concentration of magnesium in tissue cells is about four times that of erythrocytes (Wallach, Cahill, Rogan, and Jones, 1962).

The patients studied by Jones et al. (1965) were mostly in a young age group and they suggested that the effects of age and length of illness may have contributed to the high concentrations reported by Kenyon and Hardy (1963) although the latter authors state they found no such correlation. Our results show no effect of age; only two of our 10 patients were under 50 years of age, and erythrocyte magnesium concentrations, within the normal range in all but one, showed no tendency to change with increasing age. In view of the apparent normality of the erythrocyte magnesium concentration, the positive correlation with length of illness (Fig. 2) in our patients is interesting. It can be seen that the positive correlation is due mainly to the higher cell magnesium concentration in the two patients whose length of illness was more than twice as long as most of the others. If this increase is significant, it is apparently an effect rather than a cause. These

\begin{tabular}{|c|c|c|c|c|c|c|c|c|c|c|c|c|c|c|c|c|}
\hline \multirow{3}{*}{ Patient } & \multirow{3}{*}{ Sex: Age } & \multicolumn{14}{|c|}{ BLOOD RESULTS IN 10 PATIENTS WITH HUNTINGTON'S CHOREA } & \multirow{3}{*}{$\begin{array}{l}\text { [Ca } \\
\text { Produ } \\
\text { (mEq. }\end{array}$} \\
\hline & & \multirow{2}{*}{$\begin{array}{l}\text { Duration } \\
\text { of illness } \\
\text { (Yr.) }\end{array}$} & \multirow{2}{*}{$\begin{array}{l}\mathrm{Ca} \\
\text { (mg./100 } \\
\mathrm{ml.} \text { ) }\end{array}$} & \multirow{2}{*}{$\begin{array}{l}\text { Serum P } \\
\text { (mg./100 } \\
\text { ml. })\end{array}$} & \multirow{2}{*}{$\begin{array}{l}\text { Total } \\
\text { Protein } \\
(\mathrm{g} . / 100 \mathrm{ml} .)\end{array}$} & \multicolumn{5}{|c|}{ Plasma $M g(m E q . / l)}$. & \multicolumn{4}{|c|}{$\begin{array}{l}\text { Erythrocyte } \mathrm{Mg} \\
(\mathrm{mEq} . / \mathrm{l} .)\end{array}$} & \multirow{2}{*}{$\begin{array}{l}\text { Ratio } \\
M g_{\mathrm{E}}\end{array}$} & \\
\hline & & & & & & June & Sept. & Nov. & Dec. & Mean & Sept. & Nov. & Dec. & Mean & & \\
\hline $\begin{array}{l}\text { A.L. } \\
\text { M.B. } \\
\text { R.D. } \\
\text { M.A. } \\
\text { S.H. } \\
\text { M.M.W. } \\
\text { C.G. } \\
\text { N.C. } \\
\text { J.B. } \\
\text { J.B.F. }\end{array}$ & $\begin{array}{l}\text { F.34 } \\
\text { F.40 } \\
\text { F.60 } \\
\text { F.64 } \\
\text { F.64 } \\
\text { F.65 } \\
\text { F.66 } \\
\text { F.68 } \\
\text { M.45 } \\
\text { M.62 }\end{array}$ & $\begin{array}{c}9 \\
4+ \\
7+ \\
25 \\
10 \\
7 \\
4 \\
5 \\
2 \\
16\end{array}$ & $\begin{array}{r}9 \cdot 7 \\
9 \cdot 6 \\
10 \cdot 3 \\
10 \cdot 3 \\
10 \cdot 0 \\
9 \cdot 5 \\
\overline{10} \cdot 1 \\
\overline{8} \cdot 6\end{array}$ & $\begin{array}{l}4 \cdot 3 \\
3 \cdot 1 \\
4 \cdot 1 \\
4 \cdot 2 \\
- \\
4 \cdot 0 \\
3 \cdot 5 \\
3 \cdot 7 \\
3 \cdot 5 \\
3 \cdot 7\end{array}$ & $\begin{array}{l}7 \cdot 8 \\
8 \cdot 0 \\
7 \cdot 6 \\
8 \cdot 2 \\
7 \cdot 6 \\
7 \cdot 1 \\
7 \cdot 7 \\
7 \cdot 7 \\
8 \cdot 3 \\
7 \cdot 2\end{array}$ & $\begin{array}{l}1.78 \\
1.60 \\
1.77 \\
1.71 \\
1.63 \\
1.67 \\
- \\
1.60 \\
- \\
1.63\end{array}$ & $\begin{array}{l}1.79 \\
1.87 \\
1.81 \\
1.84 \\
1.63 \\
1.64 \\
1.84 \\
1.71 \\
1.75 \\
1.62\end{array}$ & $\begin{array}{l}1.68 \\
1.83 \\
1.87 \\
1.88 \\
1.70 \\
= \\
\overline{1.72} \\
= \\
-\end{array}$ & $\begin{array}{l}1.76 \\
1.69 \\
1.78 \\
1.69 \\
1.68 \\
- \\
- \\
1.64 \\
- \\
-\end{array}$ & $\begin{array}{l}1.75 \\
1.75 \\
1.81 \\
1.79 \\
1.66 \\
1.66 \\
1.84 \\
1.67 \\
1.75 \\
1.62\end{array}$ & $\begin{array}{l}5 \cdot 40 \\
5 \cdot 58 \\
5.52 \\
5.97 \\
5.56 \\
4 \cdot 89 \\
4.66 \\
4.69 \\
4 \cdot 43 \\
5 \cdot 47\end{array}$ & $\begin{array}{l}4 \cdot 51 \\
4.75 \\
5.07 \\
5 \cdot 51 \\
4.57 \\
- \\
\overline{4.32} \\
- \\
-\end{array}$ & $\begin{array}{l}5 \cdot 15 \\
5 \cdot 07 \\
5 \cdot 18 \\
5 \cdot 66 \\
4 \cdot 64 \\
- \\
- \\
4 \cdot 15 \\
- \\
-\end{array}$ & $\begin{array}{l}5.02 \\
5 \cdot 13 \\
5.26 \\
5.78 \\
4.92 \\
4.89 \\
4.66 \\
4.39 \\
4.43 \\
5 \cdot 47\end{array}$ & $\begin{array}{l}2 \cdot 87 \\
2 \cdot 93 \\
2 \cdot 91 \\
3 \cdot 23 \\
2.96 \\
2.95 \\
2 \cdot 53 \\
2 \cdot 63 \\
2.53 \\
3 \cdot 38\end{array}$ & $\begin{array}{l}16.5 \\
11.8 \\
16.5 \\
16.9 \\
\overline{14} \cdot 8 \\
\overline{14} \cdot 4 \\
\overline{12} \cdot 7\end{array}$ \\
\hline Mean & -57 & - & 9.8 & $3 \cdot 8$ & $7 \cdot 7$ & & & - & & 1.73 & & - & & 5.00 & 2.89 & $14 \cdot 8$ \\
\hline $\begin{array}{l}\text { Mean } \\
\text { S.D. }\end{array}$ & - & - & $9 \cdot 6$ & $3 \cdot 7$ & $7 \cdot 7$ & & $1.61 \pm$ & $=0.08$ & & & & $.87 \pm$ & 0.30 & & $\begin{array}{l}2.99 \\
\pm\end{array}$ & $\begin{array}{l}16 \cdot 0 \\
\pm\end{array}$ \\
\hline $\begin{array}{l}\text { Normal } \\
\text { ranges }\end{array}$ & - & - & $\begin{array}{l}8.9 \\
\text { to } \\
10.5\end{array}$ & $\begin{array}{l}3.0 \\
\text { to } \\
4.5\end{array}$ & $\begin{array}{l}6.5 \\
\text { to } \\
8 \cdot 5\end{array}$ & & 1.45 to & $1 \cdot 80$ & & & & 20 to & .50 & & $\begin{array}{l}0.30 \\
2.50 \\
\text { to } \\
3.50\end{array}$ & $\begin{array}{l}2.0 \\
12.0 \\
\text { to } \\
20.0\end{array}$ \\
\hline
\end{tabular}


two patients had been disturbed by choreiform movements and mental symptoms for many years, and were not necessarily more severely choreic than those with a shorter duration of symptoms. Also the increases were minimal. Nevertheless, it is an unavoidably positive finding and lends credence to the view that further research into magnesium metabolism in choreic patients may be worth while.

The one patient (M.A.) who consistently had high erythrocyte magnesium concentrations beyond the normal range (Fig. 1) was in the terminal stages of the illness and died shortly after the study was completed. There was no pathological evidence of renal disease or other abnormality which might have increased magnesium concentrations. During the period of investigation she was severely choreic, becoming progressively more rigid despite therapy. She was also deeply depressed in her spirits.

Like Kenyon and Hardy (1963) and others we found no consistent relationship between plasma and erythrocyte magnesium concentrations; thus the correlation between the erythrocyte:plasma magnesium ratio and length of illness was much less marked. Although it appears from Fig. 1 that plasma magnesium concentrations were mainly on the higher side of the normal range, there was no statistically significant difference between the patient's mean and the normal mean. As with the investigations of others, the significance of differences in our results is limited by the relatively small numbers of patients.

The paradox is presented that, although abnormal choreiform-type movements have been associated with hypomagnesaemia, Kenyon and Hardy (1963) suggested that there might be an associated intracellular magnesium excess in at least some cases of Huntington's chorea. Thus we have a situation in which a search is made for a possibly low extracellular magnesium concentration, and all that is found is the doubtful, or at least unconfirmed, possibility of a high intracellular concentration. Our results add to the doubt, rather than confirming normality or otherwise. If a lack of magnesium in the extracellular fluid can potentiate choreiform movements, it is difficult to explain the effects, possibly counter effects, of a high intracellular concentration, which has been shown actually to reduce neuromuscular activity (Castillo and Engbaek, 1954). Pathological changes in the basal ganglia in Huntington's chorea have been consistently found (McCaughey, 1961), and it is at the ganglia and neuromuscular junctions in particular that small increases in magnesium concentration exert their inhibiting effect on the liberation of acetylcholine. One would therefore expect increased neuromuscular activity, as seen in Huntington's chorea, to be associated with a decreased ganglionic magnesium concentration, if anything. There is of course an obvious fallacy in arguing that because erythrocyte magnesium concentrations may be increased other cell concentrations are necessarily high also, but the assumption has been apparent in previous papers (Kenyon and Hardy, 1963; Bruyn et al., 1965).

In our 10 patients, serum calcium concentration was normal. The concentration of calcium can influence the effect of alterations in magnesium concentration and vice versa, and it may be that the ratio of free calcium to magnesium ions in extracellular fluid is more important than the actual concentrations of the individual ions (Munday and Mahy, 1964). It has been suggested that the neurological symptoms in a patient with hypercalcaemia responding to magnesium therapy may have been due to intracellular magnesium depletion secondary to the high calcium concentrations (Lynch, Lemon, Henn, Ellingson, and Grissom, 1964). Conversely, magnesium has been found to accumulate in the basal ganglia of a patient with vascular calcification (Bruyn, Staal, and Bots, 1964).

At first sight our results seemed to confirm those of Jones et al. (1965) and of Bruyn et al. (1965), by failing to show any abnormality of plasma or erythrocyte magnesium concentration in nine of our 10 patients, on repeated samples taken over a period of nine months. On the other hand, our results again raise the possibility, first suggested by Kenyon and Hardy (1963), that erythrocyte magnesium could be increased in the later, perhaps terminal, stages of the disease, after prolonged duration of symptoms. We are aware that our data lack valid statistical significance and that with so few patients the two higher erythrocyte magnesium concentrations may be fortuitous. The increased erythrocyte magnesium concentrations in the patients of Kenyon and Hardy (1963) were not statistically significant either. The fact that an inherited disease generally takes until middle life to produce symptoms is an indication (Bruyn et al., 1965) that the metabolic changes producing the symptoms are likely to be minimal. However, metabolic changes resulting from or coinciding with the onset of symptoms may not also be minimal.

It is possible that future techniques may reveal some form of intracellular deficit or excess, perhaps at the neuromuscular junction or in ganglion cells. The relationship of intracellular magnesium to extracellular calcium, and the clinical or neurological effects of alterations in concentration remain to be elucidated. In view of the association of magnesium with the liberation of acetylcholine, investigation of intracellular magnesium concentra- 
tions, both free and protein-bound, in nerve and muscle cells would be worth while, and one must await the development of techniques which will enable us to study intracellular concentrations of ions in individual tissues of the living human body.

\section{SUMMARY}

Plasma and erythrocyte magnesium concentrations have been measured by atomic absorption spectrophotometry in 10 patients with Huntington's chorea. Estimations, repeated periodically over nine months, did not show an abnormality of magnesium concentration in nine of the patients. The one patient with marginally higher than normal erythrocyte magnesium concentration was in the terminal stages of illness. A positive correlation between erythrocyte magnesium concentration and duration of symptoms was noted. Investigations in a much larger series of patients would be necessary to produce statistically significant evidence of a marginal increase in erythrocyte magnesium concentration in patients with symptoms for over 15 years. It is our opinion that data of value are more likely to result from studies of intracellular tissues of nerve and muscle. The results reported here suggest that any defect in magnesium metabolism in Huntington's chorea is not reflected by changes in plasma or erythrocyte concentrations, with the exception of a possible increase in the latter after many years of the illness.

We wish to express our gratitude for the help given by our colleagues, and for permission from the superintendent physicians and consultants concerned to study these patients.

\section{REFERENCES}

Barker, E. S. (1960). Physiologic and clinical aspects of magnesium metabolism. J. chron. Dis., 11, 278-291.
Beale, R. N., and Bostrom, J. O. (1963). Sensitive methods for the titrimetric microdetermination of biological calcium and magnesium. J. clin. Path., 16, 252-255.

Bruyn, G. W., Mink, C. J. K., and Caljé, J. F. (1965). Biochemical studies in Huntington's chorea. Neurology (Minneap.), 15, 455-461.

_, Staal, A., and Bots, G. Th. A. M. (1964). Familial bilateral vascular calcification in the central nervous system. Psychiat. Neurol. Neurochir. (Amst.), 67, 342-376.

del Castillo, J., and Engbaek, L. (1954). The nature of the neuromuscular block produced by magnesium. J. Physiol. (Lond.), 124, 370-384.

Eliel, L. P., Smith, W. O., and Thomsen, C. (1960). Magnesium and calcium interrelationships. J. Okla. med. Ass., 53, 359-367.

Fiske, C. H., and Subbarow, Y. (1925). The colorimetric determination of phosphorus. J. biol. Chem., 66, 375-400.

Fleming, L. W., and Stewart, W. K. (1966). The effect of the atomiser on the estimation of magnesium by atomic abserption spectrophotometry. Clin. chim. Acta, 14, 131-134.

Flink, E. B., McCollister, R., Prasad, A. S., Melby, J. C., and Doo, R. P. (1957). Evidences for clinical magnesium deficiency. Ann. intern. Med., 47, 956-968.

Jones, J. E., Desper, P. C., and Flink, E. B. (1965). Magnesium metabolism in Huntington's chorea. Metabolism, 14, 813-818.

Kenyon, F. E., and Hardy, S. M. (1963). A biochemical study of Huntington's chorea. J. Neurol. Neurosurg. Psychiat., 26, 123-126.

Keyser, J. W. (1961). Rapid estimation of albumin and total protein in small amounts of blood serum. Clin. chim. Acta, 6, 445-447.

Lynch, H. T., Lemon, H. M., Henn, M. J., Ellingson, R. J., and Grissom, R. L. (1964). Vitamin D-intoxicated patient with hypoparathyroidism. Arch. intern. Med., 114, 375-380.

McCaughey, W. T. E. (1961). The pathologic spectrum of Huntington's chorea. J. nerv. ment. Dis., 133, 91-103.

MacIntyre, I., Hanna, S., Booth, C. C., and Read, A. E. (1961). Intracellular magnesium deficiency in man. Clin. Sci., 20, 297-305.

Martin, H. E., Mehl, J., and Wertman, M. (1952). Clinical studies of magnesium metabolism. Med. Clin. N. Amer., 36, 1157-1171.

Miller, A. (1963). The significance of serum magnesium levels. Med. J. Aust., 2, 406-407.

Munday, K. A., and Mahy, B. W. J. (1964). Determination of ultrafiltrable calcium and magnesium on small quantities of plasma. Clin. chim. Acta, 10, 144-151.

Randall, R. E., Jr., Rossmeisl, E. C., and Bleifer, K. H. (1959). Magnesium depletion in man. Ann. intern. Med., 50, 257-287.

Rizek, J. E., Dimich, A., and Wallach, S. (1965). Plasma and erythrocyte magnesium in thyroid disease. J. clin. Endocr., 25, 350-358.

Seller, R. H., Ramirez-Muxo, O., Brest, A. N., and Moyer, J. H. (1965). Magnesium metabolism in hypertension. J. Amer. med. Ass., 191, 654-656.

Wallach, S., Cahill, L. N., Rogan, F. H., and Jones, H. L. (1962). Plasma and erythrocyte magnesium in health and disease. J. Lab. clin. Med., 59, 195-210.

Welt, L. G., and Gitelman, H. (1965). Disorders of magnesium metabolism. DM (Chic.), May, pp. 1-32. 